\title{
ANATOMY OF THE SPINAL CORD'S BLOOD SUPPLY. Review
}

\author{
Chernyak V.A. \\ Shevchenko O.O. \\ Zorenko O.V. \\ Levon M.M. \\ Selivanov S.S. \\ Holinko V.M. \\ Bogomolets National Medical University, Kyiv, Ukraine \\ masha_levon@mail.ru
}

\begin{abstract}
Relevance. The traditional scheme of blood supply to the spinal cord, formed in the 60-70s of the last century, does not correspond to the pathogenesis of many neurological disorders of the spinal cord. There is also a discrepancy in terminology: the names of arteries found in surgical and neurological works do not correspond to the names of the International Anatomical Nomenclature. Therefore, today this issue needs further analysis.
\end{abstract}

Objective: to summarize the information of different authors on the number of spinal branches and their branches, topography, blood supply to each segment of the spinal cord, to analyze the individual variability of sources of blood supply to the spinal cord.

Materials and methods. Analysis of scientific publications in the international electronic scientometric database PubMed by keywords for the period 2000-2018. and comparing these data with the imaginations of 1760-1993.

Results. The idea of the structural organization of the blood supply to the spinal cord has changed. With modern data, intracranial sources, namely: anterior and posterior spinal arteries, blood supply to the true cervical spinal cord, and the rest of the department - lower cervical, thoracic, lumbar, sacral and coccygeal - blood supply from extracranial sources, and they exist in this area segmental branches of the aorta. Nowadays, extracranial sources are considered the main in the blood supply to the spinal cord. It is now known that the anterior and posterior spinal arteries are intermittent and cannot provide blood supply to the spinal cord, as previously thought. The general plan of arterial blood supply of a spinal cord can be presented in the form of set of pools of front and back radical (radiculomedullary) arteries. The anterior radicular arteries are 4-8, and the posterior 15-20, respectively, along the spinal cord in its ventral and dorsal departments the same number of arterial pools is formed. There are anastomotic connections between these pools, which are not always functionally complete. Each of these basins is supplied by a separate radiculomedullary artery. Each such artery feeds not one but several segments of the spinal cord. The number and levels of approach to the spinal cord of radiculomedullary arteries, especially the anterior ones, differ significantly in individual variability. The perception of vascularization of the cervical spinal cord was analyzed. At different times, information about the number of arteries that supplied blood to this department differed significantly: in 1760 it was believed that it was 31 arteries; and in 1882-1939 - only 7; in 1943 - 27, in 1958 - 6-8; in 1958 - 7-10; in 1961-1963 - 5-8; in 1966-1973 - 5; in 1993 - 1-2 arteries. Such different information about spinal cord vascularization is the result of significant individual variability.

Conclusions. Incomplete current knowledge about the blood supply to the spinal cord is the cause of unresolved problems of etiology, pathogenesis and clinical course of spinal ischemic strokes, including cervical localization. The existing terminological confusion regarding the names of the arteries that supply blood to the spinal cord, in particular its cervical region, is explained by the significant variability of the radiculomedullary arteries of this zone in terms of number, diameter and location. Due to the existence of arterio-venous anastomoses, arterial myelobulbar anastomoses, adjacent areas of blood supply in this area, theft phenomena are formed and distant foci of ischemia appear, including both the spinal cord and the brain. Therefore, in order to make an angiotopic diagnosis, it is necessary to take into account not only anatomical, but also physiological and pathophysiological aspects of regulation and compensation of cerebral circulation.

Keywords: spinal cord vascularization, cervical region, radiculo-medullary arteries.

Relevance. Acute cerebrovascular disorders often lead to irreversible neurological damage, which is accompanied by the development of persistent disability of the patient [16]. According to statistics, spinal strokes account for about $1 \%$ of all (cerebral and spinal strokes together), and some authors believe that the exact prevalence of spinal strokes is not known for sure $[3,16]$. This pathology is quite rare, and, despite the urgency of the problem, the clinical and morphological features of spinal strokes are insufficiently studied. The fact that spinal strokes occur much less frequently than cerebral strokes can be explained by the small size of the spinal cord, the large number of arterial anastomoses and the lower prevalence of atherosclerotic lesions of the spinal arteries [18]. Cervical strokes cause the most severe neurological disorders: from muscle weakness to paraplegia or tetraplegia, depending on the level and depth of the lesion, and in cases of ischemia to the brainstem - rapid death.

Nowadays, the sources of blood supply to the spinal cord are generally described; these data are set out in textbooks on normal anatomy. However, the literature data on a detailed description of the blood supply to different parts of the spinal cord and the distribution 
of intravascular vessels of the spinal cord, taking into account individual variability, is extremely small, and these sources date mainly to the $60-70$ s of last century.

So the blood supply to the spinal cord is an extremely important and urgent problem, but at the same time little studied, which requires further study.

Objective of this work was to summarize the information of different authors on the number of spinal branches and their branches, topography, blood supply to each segment of the spinal cord, to analyze the individual variability of spinal blood supply sources.

\section{MATERIALS AND METHODS}

Analysis of scientific publications in international electronic scientometric databases by keywords for the period 2000-2018. and comparing these data with the imaginations of 1760-1993.

\section{RESULTS}

From the XVIII and almost to the end of the XIX century in anatomy there was a stable idea of the blood supply to the spinal cord, which will be set out in almost all anatomical textbooks, both domestic and foreign [1, $10,11,15,20]$. According to traditional notions, the main sources of spinal cord supply are three arterial trunks: unpaired anterior and paired posterior spinal arteries (branches of the vertebral arteries of the subclavian artery - right and left). The anterior and posterior spinal arteries run along the spinal cord in the rostrocaudal direction. Blood in these arteries comes from the intracranial part of the right and left vertebral arteries and then flows continuously along the entire spinal cord. Posterior spinal arteries start from the posterior inferior cerebellar artery (branches of the intracranial part of the spinal artery) or directly from the intracranial part of the spinal artery, encircle the medulla oblongata, enter the spinal canal and go to the posterior surface of the spinal cord. which include the posterior radicles. The right and left anterior spinal arteries depart from the corresponding vertebral artery at the level of the anterior edge of the occipital foramen, on the anterior surface of the medulla oblongata at the level of the pyramids, and form an unpaired anterior spinal artery, which goes down on the anterior surface of the spinal cord.

An additional source of blood supply to the spinal cord were considered to be the radicular arteries (branches of the spinal arteries), which correspond to each segment of the spinal cord, have the same diameter and increase blood flow in the main longitudinal arteries.

But the traditional scheme of blood supply to the spinal cord did not correspond to the pathogenesis of many neurological disorders of the spinal cord. Gradually, under the influence of the work of many scientists [2, $4,5,13]$, our ideas about the structural organization of the blood supply to the spinal cord change. According to current data, intracranial sources, namely the anterior and posterior spinal arteries, supply blood only to the upper cervical segments of the spinal cord, and the remaining segments - lower cervical, thoracic, lumbar, sacral and coccygeal - are supplied from extracranial sources, namely from the branches of the subclavian artery. branches of the aorta. Thus, in our time, extracranial sources are considered the main in the blood supply to the spinal cord $[2,4,5,13]$.

Despite the identification of priority sources of blood supply to the spinal cord, there are still many controversial and unresolved issues regarding the detailed description of its blood supply, especially the cervical region. These specific issues concerning the number of spinal branches and their branches, topography, blood supply to each segment of the spinal cord, etc., are the most important in clinical practice, because they determine the development and features of pathological lesions of certain parts of the spinal cord. Little is known about the individual variability of spinal blood supply sources. There is still a terminological discrepancy between the names of the arteries that supply blood to the spinal cord: the names of the arteries found in surgical and neurological works do not correspond to the names of the International Anatomical Nomenclature [8].

The founders of the modern concept of blood supply to the spinal cord are A. Adamkiewicz (1881-1882) and H. Kadyi $(1886,1889)$, who in the nineteenth century from other points of view covered the blood supply to the spinal cord. A. Adamkiewicz first proved that the number of spinal arteries is reduced and does not correspond to the number of segments of the spinal cord. The author called these arteries «spinal», and their branches anterior and posterior spinal arteries. According to A. Adamkiewicz, 3 to 13 anterior spinal arteries are defined. The largest diameter of the anterior spinal (root) artery in the caudal part of the spinal cord, the author called A. magna spinalis. Later, this artery became known after the author who described it - Adamkevich's artery.

H. Kadyi proposed the terms «radicular» branches instead of anterior and posterior spinal arteries, so as not to confuse them with the anterior and posterior spinal arteries. In the modern anatomical nomenclature (São Paulo, 1997) and its Ukrainian standard (2001), the anterior and posterior root branches and the segmental cerebral artery are distinguished among the branches of the spinal arteries. The term «radiculomedullary arteries» dominates in textbooks and scientific literature on neurology. The segmental cerebral artery, as a branch of the spinal artery, is practically not described in the modern anatomical and neurological literature. According to some data, the segmental cerebral artery connects with the anterior spinal artery [8]. According to other data, the segmental artery is part of the posterior root of the spinal nerve and is involved in the blood supply to the spinal cord.

Subsequent work has shown that the main source of blood supply to the spinal cord are the root arteries, 
and their number is much smaller than the number of segments of the spinal cord.

The radicular arteries in the upper parts of the spinal cord are branches of the spinal branches that extend from the spinal artery (right and left). In the lower parts of the spinal cord, the root branches are branches of the spinal branches coming from the posterior intercostal arteries (segmental branches of the thoracic aorta), lumbar arteries (segmental branches of the abdominal aorta), and lateral sacral and iliac-lumbar arterial arteries. Due to the fact that in embryogenesis the spinal cord lengthens more slowly than the spinal column grows, the segmental arteries enter the spinal cord above the level of their departure from the aortic trunk.

Determine the anterior and posterior radicular arteries. The anterior radicular arteries accompany the anterior radicles of the spinal nerve, and the posterior respectively, the posterior radicles of the spinal nerve.

It is proved that the radicular arteries approach the spinal cord not symmetrically, but more often from the left side. The anterior radicular arteries enter the spinal cord along its length alternately: then left, then right. Symmetrical approach of two such arteries to one spinal segment is rare. Much more often these arteries enter the spine and spinal cord on the left side. This is due to the left location of the aorta. With a right-sided location, the artery, crossing the spine in front, goes a long way.

The radicular arteries, although they accompany the nerve roots, most of them are not directly involved in the blood supply to the spinal cord. According to H. Kadui, only $25 \%$ of the radicular arteries passing into the spinal canal are involved in the blood supply to the spinal cord.

The beginning of the radicular artery can be said only from the moment of entry of the spinal branch into the subdural space.

The radicular arteries are divided into several types:

- part of the radicular arteries end within the root of the spinal nerve,

- part of the radicular arteries ends in the dura mater (these are the dura mater arteries),

- part of the radicular arteries joins the pial vascular system (vascular system of the soft membrane of the spinal cord),

- part of the radicular arteries that reach the spinal cord, merge with the anterior and posterior spinal arteries and take a major part in the blood supply to the spinal cord.

Those radicular arteries that reach the spinal cord and merge with the anterior and posterior spinal arteries are referred to in the neurology literature as the radicularspinal or radiculomedullary arteries. These arteries play a major role in the blood supply to the spinal cord.

The anterior radicular arteries are smaller, but they are larger in diameter. As a rule, it is determined from 2 to 27 anterior radicular arteries (often 4-8) and from 6 to 28 posterior radicular arteries (more often 15-20). In the cervical anterior radicular arteries in most cases there are
3 , in the upper and middle parts of the thoracic 2-3 thin anterior radicular arteries are determined, and the lower thoracic, lumbar and sacral spinal cord receive blood from 1 to 3 anterior radicular arteries [6] .

The largest anterior radicular (radiculomedullary) artery (up to $2 \mathrm{~mm}$ in diameter) is the lumbar thickening artery (Adamkevich's artery), which supplies blood to the lower half of the thoracic segments, lumbar, sacral and coccygeal segments. The level of discharge of this artery from the posterior intercostal or lumbar artery is variable. In $75 \%$ of people it varies from the level of Th8 to L2.

The anterior root branches provide blood supply $4 / 5$ of the cross section of the spinal cord.

The anterior parts of the spinal cord are mainly supplied with blood by 6-8 radicular (radicular or radiculomedullary arteries). They depart from certain arteries, but the level and direction of discharge may vary. C3 departs from the spinal artery. C6 - usually from the deep carotid artery, C8 - from the rib-neck trunk. In $10 \%$ at the lower cervical level there is no anterior radicular artery.

The largest anterior radicular arteries are identified in the middle cervical spinal cord (cervical thickening artery, or Lazort's artery) and in the inferior thoracic or upper lumbar region (lumbar thickening artery, or Adamkevich's artery). In $15-16 \%$ the large anterior radicular artery which accompanies an anterior root of L5 or S1 (Deprozh-Gotteron's artery) is defined. There are variants when the upper additional anterior radicular artery accompanying one of the thoracic roots is determined [9].

The areas of entry of the radicular arteries into the spinal canal are quite variable. For example, the Adamkiewicz artery may enter the spinal canal at the level of the 9th thoracic to 2 lumbar vertebrae.

Although the posterior radicular arteries are larger, they are less powerful and play a smaller role in the blood supply to the spinal cord as a whole.

At the level of C7-8 - T1 posterior radicular arteries are absent in $10 \%$.

Each anterior and posterior radicular arteries, approaching the surface of the spinal cord, are dichotomously divided into ascending and descending branches, which are widely anastomosed with similar branches above and below the radicular arteries. These anastomoses below the upper cervical segments on the anterior surface of the spinal cord in the anterior middle slit form the anterior anastomotic tract - anterior spinal artery, and on the posterior surface, respectively, in the posterior lateral sulcus form posterior anastomotic tracts - posterior spinal arteries [9].

Along the anastomotic tracts, areas with oppositely directed blood flow are defined, which are located, as a rule, in the place of division of the main trunk of the radicular artery into ascending and descending branches [9]. Thus, the anterior and posterior spinal arteries, on 
the one hand, are longitudinal anastomoses between the respective ascending and descending branches of the anterior and posterior radicular arteries, and on the other hand, due to their branches connecting the anterior and posterior spinal arteries, form transverse anastomoses between the anterior and posterior radicular arteries.

Numerous transverse anastomoses are formed between the anterior and posterior spinal arteries, which together form the crown of the spinal cord on the cross sections [13].

From the anterior spinal artery or anterior anastomotic tract, depart the central branches that supply $80 \%$ of the spinal cord: anterior and lateral cords, anterior and lateral horns, the base of the posterior horns, the central area around the central canal and partially the posterior cords. The posterior spinal arteries (posterior anastomotic tracts) supply blood to the posterior horns, most of the posterior cords, and the posterior lateral cords. The areas of the spinal cord that are located in critical areas on the border of the anterior and posterior spinal arteries are the worst supplied with blood: this is the base of the posterior horns, the substance around the central canal, the posterior adhesion.

The posterior spinal arteries form a large number of branches that anastomose with each other and with the anterior spinal artery. These branches are sometimes called coronal, they surround the perimeter of the spinal cord and are involved in the formation of the coronary artery plexus, or pialic network. The branches of this plexus, as well as the coronary arteries enter the substance of the spinal cord and provide blood supply to the marginal parts of the white matter.

According to modern notions, the blood supply system of the spinal cord consists of two parts: vertical (along the spinal cord) and transverse. The vertical part of the spinal cord blood supply system is formed by the anterior and posterior spinal arteries, which are often called anterior and posterior spinal arteries in the literature, and branches of the spinal branches from the subclavian artery system and segmental branches from the thoracic and abdominal aorta.

It is now known that the anterior and posterior spinal arteries are intermittent and cannot provide blood supply to the spinal cord, as previously thought. The anterior spinal artery is formed at the level of $\mathrm{C} 1-\mathrm{C} 2$ due to the fusion of the right and left anterior spinal arteries. Below this level along the anterior surface of the spinal cord, the anterior spinal artery is an anastomotic tract, which is formed by the corresponding, rather large in diameter, anterior radicular branches (from 2 to 5-6).

At the level of the segment where the anterior spinal artery is approached by the anterior radicular (radiculomedullary) arteries, blood flow has the opposite direction: along the ascending branch - cranial, and along the descending branch - caudal. The anterior spinal artery is represented by a continuous trunk in the cervical and lumbosacral spinal cord, and at the level of the mid-thoracic artery this artery is interrupted. Below the cervical segments, the paired posterior spinal arteries are less developed and are formed from 10-23 posterior radicular arteries, representing a continuation of the posterior radicular arteries, which are oriented upwards and downwards. Below the cervical segments due to incomplete fusion of the posterior radicular arteries in some areas the lumen of the posterior spinal arteries may be absent.

Blood from the spinal arteries steadily flows only to the upper cervical segments. Further, due to the decrease in their diameter, increase in blood flow resistance, decrease in pulse blood pressure, intermittent lumen, blood flow in the cerebral arteries is almost absent. Therefore, starting from the cervical segments, the source of blood supply to the spinal cord is the radicular arteries [14].

In the vertical part of the spinal cord blood supply system there are two hemodynamic arterial pools: upper and lower. The upper basin (or spinal subclavian), which supplies blood segments $\mathrm{C} 1-\mathrm{Th} 2$, includes the anterior and posterior spinal arteries, which supply blood C1-C4 segments; and 3-7 radicular arteries that supply blood to the rest of the cervical and 2-3 upper thoracic segments. The lower pool (or aortic pool) supplies blood to the lower segments of Th3-S5, which receive blood from the segmental branches of the aorta.

On a cross section define three pools, or zones of blood supply, a spinal cord. The first zone is central, occupies a middle position and is the largest in terms of blood supply. The central zone includes the anterior horns, anterior gray adhesions, adjacent areas of the lateral and anterior cords. The central zone is supplied with blood by paired furrowed branches from the anterior spinal artery. Each of these arteries supplies blood only to the corresponding half (right or left) of the cross section of the spinal cord. The second zone of blood supply is dorsal, formed by the immersion branches of the posterior spinal arteries. The dorsal arterial area of blood supply includes the posterior horns and posterior cords. The third arterial zone is a periodic situation, on the cross section of the spinal cord it performs the marginal sections of the transitional and lateral canals. This area receives blood supply from the immersion branches and from the existing areas of the perimedullar network (vase-crown network) and the pial vascular network.

Depending on the number of root arteries, there are two types of spinal cord blood supply: main and placental. A small number of radicular arteries - 3-5 anterior and 6-8 posterior - determines the main type of blood supply to the spinal cord. The main type determines the extreme variant, when only 3-4 anterior radicular arteries supply blood to the cervical and upper thoracic segments of the spinal cord, and the lower thoracic, lumbar, sacral and coccygeal segments are supplied with only one anterior radicular artery - Adamkevich's artery. The main type of blood supply to the spinal cord is determined in $48 \%$. There is a variant when the spinal cord below ThI - Th2 
is supplied with blood by only one Adamkevich artery $(12 \%)$. In the presence of placer type, the radicular arteries supplying blood to the spinal cord are much larger - 6-12 anterior and 22 or more posterior [9]. Each anterior radicular artery supplies blood to several adjacent segments of the spinal cord, so in the presence of circulatory disorders in one of these arteries, blood flow is relatively easily compensated. The loose type of blood supply is determined in $42 \%$. The type of blood supply to the spinal cord is genetically determined and affects the formation of the spinal arteries in the lower parts of the spinal cord. In the presence of the main type of blood supply to the spinal cord, the anterior spinal artery in the lower basin is formed by branches of one radicular artery $(20 \%)$ or two radicular arteries: upper accessory radicular artery.

In the pool of blood supply to the spinal cord, both in the vertical and horizontal planes, critical areas are identified in which there is a low level of arterial blood flow.

According to modern ideas, the anterior and posterior spinal arteries are not continuous vessels, and blood flow in these vessels may have the opposite direction, which leads to the formation along the long axis of the spinal cord border areas of blood supply (levels C4, Th4, Th9 - L1).

Along the spinal cord in the longitudinal direction there are also areas of reduced blood circulation, located on the border of the basins of the radicular (radiculomedullary arteries). These critical areas are variable in size because it determines the significant individual variability in the number of radicular arteries and the level of their entry into the spinal cord. Most often, such critical areas include the upper thoracic segments, the area of the spinal cord above the lumbar thickening and the terminal part of the spinal cord.

From the point of view of conditions of hemodynamics, in longitudinal arterial vessels allocate other critical zones of blood supply of a spinal cord. Thus, in the process of anatomical examination it was noticed that the smallest diameter of the anterior spinal artery is mainly found in the middle between the lateral tributaries (anterior root). Proponents of Adamkevich's theory of the direction of blood flow in the longitudinal spinal arteries believe that it is in these narrow areas of the artery are opposite directions of blood flow. This hypothetical zone of zero pressure in the area of relative narrowing of the vascular bed, apparently, is a functional watershed between two adjacent radiculo-medullary basins. Such areas are called «border» or «adjacent» zone. This area includes both part of the longitudinal arterial tract and the area of the spinal cord that supplies them with blood. These border areas are especially vulnerable to circulatory failure.

K.J. Zulch identified an intermediate zone at the level of Th4-Th9 between the upper and lower arterial basins, which is insufficiently supplied with blood by the anterior root artery, which goes together with the roots of
Th6-Th7. He localized a particularly threatening «critical zone» as the boundary between the vertebral and aortic basins in the Th4 segment. Other critical areas are located between the upper and lower tributaries in the cervical thickening $\mathrm{C} 3-\mathrm{C} 4$ and between the lower thoracic and upper lumbar tributaries - approximately L1-2.

Unlike K.J. Zulch, some authors have noted that softening is most common in areas of spinal cord thickening. According to C. Fazio (1965), at the level of the cervical segments, the danger zone is the area $\mathrm{C} 3$ C4. According to J. Corbin (1960), ischemic strokes are localized in the areas of cervical and lumbosacral thickenings.

Given the great variability in the location of arterial sources, it is impossible to insist on the stability of border areas and strictly link them to certain spinal segments. The only exception is the adjacent area between the two main remote arterial basins: the vertebral-subclavian and aortic. This zone is quite permanent. This is evidenced by experimental data, which showed that when excluding the aortic basin, the lower limit of the filling of the vascular system is at C8-Th3. According to K. Jellinger, the boundary zone between the two main sections of human blood flow is not at the level of Th4, as suggested by K. J. Zulch (1954), and above - at C8-Th 1-2.

From the point of view of physiology of dynamics of blood circulation, for a spinal cord there are two opposite concepts about the greatest defeat of pools of blood supply and localization of secondary changes at condition of vascular insufficiency. Proponents of one concept believe that the most commonly affected areas with insufficient vascularization are the thoracic segments in the vertical plane. In the transverse plane - these are the areas between the central and peripheral areas of blood supply to the spinal cord. The founders of another theory, on the contrary, believe that the most vulnerable are areas that are heavily supplied with blood and functionally active in conditions of reduced arterial blood flow. In the vertical plane, these are the areas of cervical and lumbosacral thickenings. In the transverse plane, this is the central area that is most functionally active.

Thus, the blood supply to the spinal cord is carried out mainly by a reduced number of segmental arteries. G. Lazorthes called this phenomenon a «summation» of the radicular arteries.

Therefore, the general plan of arterial blood supply of a spinal cord can be presented in the form of set of pools of front and back radical (radiculomedullary) arteries. If we keep in mind that on average the anterior root arteries are 4-8, and the posterior 15-20, then, respectively, along the length of the spinal cord in its ventral and dorsal departments the same number of arterial pools is formed. There are anastomotic connections between these pools, which are not always functionally complete. Each of these basins is supplied by a separate radiculomedullary artery. Each 
such artery feeds not one but several segments of the spinal cord. The number and levels of approach to the spinal cord of radiculomedullary arteries, especially the anterior ones, differ significantly in individual variability [13].

According to estimates by K. Jellinger, who studied 700 drugs, the largest number of anterior root arteries passes to the cervical thickening at the height of C5C7, slightly less - to the caudal thoracic segments (at the height of Th6-Th10). In the thoracolumbar region (Th10-L2), in the upper cervical segments (C3-C4) the number of drives is much smaller. The minimum part falls on the transitional cervical-thoracic region (C3-Th2) and the lower lumbar segments (L3-L4). Intraorganic vessels of the spinal cord, belonging to the basin of the anterior radicular arteries and anterior spinal artery, form the central part of the arterial system of the spinal cord and supply blood in the direction from the center to the periphery of the spinal cord area, which is $4 / 5$ of its diameter. The remaining $1 / 5$ of the spinal cord, located mainly in the marginal areas of white matter, feeds mainly on the perimedullar vascular network, which in turn receives blood from the posterior radicular and posterior spinal arteries (they are always larger than the anterior, but they are almost in diameter twice as thin as its previous counterparts) [13].

Counting the frequency of active root arteries at the level of individual segments of the human spinal cord (400 drugs), K. Jellinger noticed that the lowest frequency of both anterior and posterior arteries occurs at the level of C3-Th1-2. On this basis, he suggested that the C8Th1-2 segments often represent the anatomical boundary between the two basins - the subclavian and aortic.

The number of functioning coronary arteries is very variable. It should be noted that variability is available within individual vertical basins. In the same case, in the lower arterial basin there may be 1-2 anterior radicular (radiculomedular) arteries, while in the upper basin there may be much more [13].

M. Maliszewski, having studied 50 preparations of the spinal cord and assessing the location, diameter and ligaments of blood vessels, identified 7 vascular areas: upper cervical area (C1-C3), middle cervical area (C4-C5), cervical thickening (C6-C8), upper thoracic zone (Th1-Th3), middle thoracic zone (Th4-Th7), thoracolumbar thickening (Th8-L4) and lumbosacral zone (L5-Co1-3).

Богородинський Д.К., Скоромець О.А. розглядаються два основних шляхи кровопостачання спінного мозку, відкриваючи від дугі аорти. Верхній басейн із хрестовими та іншими провідними гілок підключичного артерію (a. Vertebralis, a. Cervicalis ascendens et profundus, intercostalis suprema). The radicular branches of these arteries provide nourishment to all cervical and first or second upper thoracic segments of the spinal cord (upper arterial pool of the spinal cord). The second way of blood supply is provided by segmental branches of an aorta and internal iliac arteries (aa. Intercostales posteriores, subcostalis, lumbales, lumbalis ima, ilio-costalis, sacralis lateralis et mediana). This lower arterial basin of the spinal cord includes all its segments below Th2. In some cases, at the level of the lower basin there is only one anterior radiculomedullary artery - Adamkevich's artery. This demonstrates that the isolated G. Lazorthes and J.L. Corbin third, the socalled intermediate, arterial zone does not always occur. In addition to these anatomical findings, the feasibility of dividing the blood supply to the spinal cord into two basins is also dictated by clinical considerations. At disturbance of blood circulation in the top arterial pool tetraparesis usually arises, but quite often at the same time stem symptoms (myelobulbar defeats) can join also. The clinical sign of circulatory disorders in the lower basin is lower paraparesis.

Let's focus in more detail on the blood supply to the cervical spinal cord.

According to classical notions, the cervical spinal cord is supplied with blood by branches from the subclavian artery basin, namely: spinal artery - paired (branches of the right and left subclavian arteries), ascending carotid artery - paired (branches of the right and left thyroid-cervical trunk from the subclavian trunk from deep carotid and the highest intercostal arteries paired (branches of the right and left costal-cervical trunk from the subclavian arteries).

Sources of blood supply to the cervical spinal cord are divided into two groups: intracranial and extracranial.

Intracranial sources are the anterior spinal artery. The right and left anterior spinal arteries depart from the intracranial part of the corresponding vertebral artery at the level of the anterior edge of the occipital foramen, exit the skull and on the anterior surface of the medulla at the pyramids connect at an acute angle and form an unpaired anterior spinal artery. the middle of the furrow. Thus, on the anterior surface of the lower part of the brain stem and upper cervical segments, a vascular rhombus or vascular circle is formed, the upper sides of which form parts of the vertebral arteries at the junction with the main artery, and the lower sides are the right and left cerebral arteries in front of them. connection. This vascular circle was named by Zakharchenko MA «Circulus arteriosus bulbaris». The lower part of the vascular rhombus is located either on the ventral surface of the medulla oblongata or on the anterior surface of the cervical segment. And from the vessels of the lower part of this circle depart the so-called «sulcal» arteries, which supply blood not only to the structures of the medulla oblongata, but also the upper cervical segments. Given this, the described arterial complex, it might be correct to call «circulus arteriosus myelobulbaris».

According to Adamkiewicz, thin branches depart from each vertebral artery, which go to the ventral surface of the medulla oblongata obliquely down and medially. Adamkiewicz called these branches vertebrospinal. 
They combine with each other either within the medulla oblongata, or more often at the height of the 2nd and 3rd cervical segments. This is how the only anterior spinal artery is formed here. G. Lazorthes emphasizes that the anterior spinal artery at the upper cervical level is always much thinner than depicted in earlier manuals. In addition to the anterior spinal artery, from the intracranial part of both vertebrae, sometimes from the inferior cerebellar arteries, originate two posterior spinal arteries that run along the posterior surface of the superior cervical segments [13].

Blood is thought to flow evenly from the right and left vertebral arteries to the corresponding anterior spinal arteries, but studies have shown that the contribution of one of the vertebral arteries is greater.

On direct X-rays, the anterior spinal artery is first oblique, then it is located strictly along the midline to the $\mathrm{C} 4$ vertebra, where it connects with the ascending branch of the radicular (radiculomedullary) artery of the cervical thickening. Another radiculomedullary artery is often present at this level. In lateral images, the anterior spinal artery runs along the posterior surface of the arches and the tooth of the second cervical vertebra, below - along the posterior surface of the vertebral bodies.

During the upper cervical segments, the anterior spinal artery retains its lumen, so it directly supplies blood to the upper cervical segments of the spinal cord. In addition to the upper cervical segments of the spinal cord, the anterior spinal arteries also supply blood to the anterior part of the medulla oblongata, the pyramids, the lower part of the spinal cord, the posterior longitudinal bundle, and the sublingual nerve nucleus.

Sometimes in section $\mathrm{C} 1-\mathrm{C} 4$, an additional anterior radicular artery is identified, which goes along with the third or fourth anterior radicle.

Extracranial sources are spinal branches (rr.spinales), which depart from the transverse (cervical) part of the vertebral arteries, paired deep cervical, ascending cervical and superior intercostal arteries.

As a rule, there are no anterior root arteries in the area of the first cervical segments. However, the posterior carotid arteries from the vertebral arteries are suitable for the upper cervical segments. At the level of the cervical region, the large anterior root arteries most often depart from the deep artery of the neck, rather than from the vertebral arteries, as previously thought.

Thus, the first upper cervical segments receive blood from the anterior spinal artery. The lower cervical segments (C4-C8) and the upper thoracic segments (Th1-Th3) are supplied with blood by two unpaired root arteries, which go to the right or left and depart either from the vertebrae or from the ascending carotid artery and rib-carotid trunk.

The cervical thickening has a dense network of blood capillaries, especially in the deep part of the anterior horns. At the level of cervical thickening, each motor motoneuron is surrounded by a three-dimensional capillary network. Experimental studies have shown that the highest blood flow velocity is determined in the area of cervical and lumbosacral thickenings (VI Klevtsova, 1968).

The number of anterior and posterior radicular arteries in the cervical spinal cord is quite variable (Table 1) [13].

From the rib-cervical trunk to the left or right there is a rather large branch, which supplies blood to the lower segments of the cervical spinal cord. This artery has the shape of a «hairpin», it connects with the ascending branches to the anterior spinal artery. In some cases, there is a variant of blood supply to the spinal cord by the anterior radicular (radiculomedular) artery extending from the thyroid-cervical trunk [13].

F. Schweighofer on 23 corpses by injection of the vessels of the cervical spinal cord found that the anterior radicular (radiculomedullary) artery only in one case departed from the spinal artery. In other cases, it departed from the deep artery of the neck. Occasionally, he found a large radiculomedullary artery (up to the cervical thickening) that receded directly from the left subclavian artery.

One of those arteries that reach the cervical thickening sometimes has a larger diameter than the others. As a rule, such an artery is located lower than the others, departing from the radicular artery of the thyroid-cervical trunk, which goes together with the 7th or 8th radicles; sometimes it passes with the 6 th and 7 th cervical radicles; less often this artery is a branch of the vertebral or deep

The number of anterior radicular arteries in the cervical spinal cord, according to the literature

\begin{tabular}{|l|c|c|c|}
\hline \multicolumn{1}{|c|}{ Автор } & Year & The average number of arteries & Number of spinal cord samples \\
\hline A. Haller & 1760 & 31 & 6 \\
\hline A. Adamkiewicz & 1882 & 7 & 13 \\
\hline F. Suh, L. Alexander & 1939 & 7 & 15 \\
\hline M. I. Jевантовський & 1943 & 27 & 48 \\
\hline G. Lazorthes & 1958 & $6-8$ & 62 \\
\hline L. Gillian & 1958 & $7-10$ & $5-8$ \\
\hline J. Corbin & 1961 & $5-8$ & 235 \\
\hline T. Mannen & 1963 & $5-8$ & 303 \\
\hline K. Jellinger & 1966 & 5 & 78 \\
\hline $\begin{array}{l}\text { D. Bogorodinsky, } \\
\text { O. Skoromets }\end{array}$ & 1973 & 5 & 23 \\
\hline F. Schweighofer & 1993 & & \\
\hline
\end{tabular}


carotid artery. Lazorthes proposed to call this artery «artery of cervical thickening», by analogy with the artery of lumbar thickening described by Adamkevich. This comparison is based on the clinical importance of the artery, although it is not valid for the diameter and frequency with which it occurs.

However, the term has not been fixed in the literature. European and domestic scientists call it differently: as a Lazort artery, as a cervical thickening artery, as a large cervical radiculomedullary artery, as a C7-radicular artery, but always emphasizing its clinical significance $[7,12,13,19,21]$.

Japanese researchers on sectional material ( 87 corpses) found a total incidence $(88.5 \%)$ of a special artery, which she called the «additional ascending artery of the neck», which originates from the subclavian artery behind the anterior ladder muscle and lies on the brachial plexus [ 21]. This study is consistent with their previous studies, in which this artery was detected in $86 \%$ of cases. The discharge and topography of this artery presented in this study correspond to the vessels previously described as the «unknown branch» or «deep ascending artery of the neck.» On 154 sides (88.5\%), the additional ascending artery of the neck extended from the subclavian artery behind the anterior ladder muscle. Among them: this artery departed as a separate artery on 105 sides, or as a common trunk with a rib-neck trunk on 31 sides, with a transverse artery of the neck on 16 sides, or with them both on 2 sides. On 69 sides of 174 sides (39.7\%) the additional ascending artery of the neck formed a common trunk with a rib-neck trunk medially from the anterior ladder muscle or behind it on 44 sides $(25.3 \%)$, or with a transverse artery of the neck (type B or C, according to Outi) behind the anterior ladder muscle or laterally from it on 20 sides $(11.5 \%)$. Rarely, an additional ascending artery of the neck formed a common trunk with the rib-neck trunk or with the transverse artery of the neck medially from the muscle or behind it ( 3 sides, $1.7 \%$ ), or from the thyroid-neck trunk ( 2 sides, $1.1 \%$ ). This study showed that the additional ascending artery of the neck gives branches to the 6th and / or 7th cervical roots of the humeral plexus. These branches are considered as characteristic or important arteries departing from the original artery [21].

Thus, the literature on the blood supply to the spinal cord is small, outdated and contradictory [17], which requires further study. And the current terminological confusion regarding the names of the arteries that supply the spinal cord, including the cervical region [7, $12,13,19,21]$, is due to the significant variability of radiculomedular arteries in this area in number, diameter and location [13]. And this is also a serious problem that needs to be solved.

\section{CONCLUSIONS}

1. Literature data covering in detail the current aspects of blood supply to various parts of the spinal cord are insufficient, and these sources date mainly to the 6070 s of last century. These gaps are the cause of unresolved problems of etiology, pathogenesis and clinical course of spinal ischemic strokes, including cervical localization, and need further study.

2. The current terminological confusion regarding the names of the arteries that supply blood to the spinal cord, in particular its cervical region, is explained by the significant variability of the radiculomedullary arteries of this area in number, diameter and location. And this is also a serious problem that needs to be solved.

3. To make an angiotopic diagnosis it is necessary to take into account not only anatomical but also physiological and pathophysiological aspects of regulation and compensation of cerebral circulation, because in connection with the existence of arteriovenous anastomoses in this area, arterial myelobulbar anastomoses, robbery phenomena are formed and distant foci of ischemia appear, including both the spinal cord and the brain.

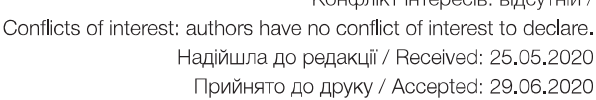

\section{REFERENCES}

1. [Human anatomical atlas: translation from the 8th English edition. - 3rd edition / F. Martini. - K.: Medicine, 2018: 128 p. [in Ukrainian]. URL: https://znannia.com.ua/ product/anatomichnii_atlas_lyudini_pereklad_z $8 \mathrm{go}$ angliis 4 kogo vidannya angliis 4 koyu ukrains 4 koyu rosiis4koyu_ta_latins4koyu_movami_frederik_martini

2. Badalyan L.O. [Neuropathology. Textbook]. - M.: Academy, 2007: 400 p. [in Russian]. URL: https://gist. github.com/anonymous/3b87d7333a618a83f64a0bfbd 2313a10

3. Vilensky BS. [Emergencies in neurology: A guide for physicians]. - S.-Pb.: FOLIANT, 2004: 512 p. [in Russian].

4. Guzeva VI. [Handbook of Pediatric Neurology]. - M.: MIA, 2009: 640 p. [in Russian]. URL: https://www. booksmed.com/nevrologiya/2625-rukovodstvo-podetskoy-nevrologii-guzeva.html

5. [Pediatric neurology. Textbook in 2 vol. / ed. O.S Petrukhin]. - M.: GEOTAR-Media, 2018: 272 p. [in Russian]. URL: http://www.geotar.ru/lots/NF0009635.html

6. Zhulev NM, Badzgaradze Yu. D., Zhulev SN. [Osteochondrosis of the spine. Manual for physicians]. - S.-Pb.: Lany, 1999: 592 p. [in Russian]. URL: https:// www.booksmed.com/nevrologiya/2827-osteohondrozpozvonochnika-zhulev.html

7. Lutsik AA, Kazantsev VV, Bondarenko G.Yu., Peganov AI. [Vascular myelopathy, caused by compression or stenosis abnormal vertebral artery, supplying the thickening of the cervical spinal cord] // Medicine in Kuzbass. 2014;13 (2): 55-62 [in Russian]. URL: http:// mednauki.ru/index.php/MK/issue/viewIssue/114/114

8. [International anatomical nomenclature: Ukrainian standard: Textbook] / ed. II Bobryk, VG Koveshnikov. 
- K.: Zdorov`ya, 2001: 327 p. [in Ukrainian]. URL: http://library.univer.kharkov.ua/OpacUnicode/ index.php?url=/notices/index/IdNotice:261458/ Source:default\#

9. [Nervous diseases: a textbook for medical students] / ed. MM Odinaka. - S.-Pb.: SpetsLit, 2014: 526 p. [in Russian]. URL: https://speclit.su/image/catal og/978-5-299-00587-5/978-5-299-00587-5.pdf

10. Netter F. [Atlas of human anatomy] / Ed. N.O. Bartosh, L.L. Kolesnikov. - M.: GEOTAR-Media, 2007: 624 p. [in Russian]. URL: http://www.medlan.samara. ru:8006/images/1-349.jpg

11. Olson T. R. [Atlas of human anatomy. A.D.A.M.] - M.: Med. lit., 2012.2012: 504 p. [in Russian]. URL: https:// $\mathrm{kim}$. by/catalog/anatomiya-i-fiziologiya/atlas-anatomiicheloveka.-a.d.a.m.

12. Popelyansky Ya. Yu. Orthopedic neurology (vertebroneurology). A guide for doctors. - M: MEDpress-inform, 2011: 672 p. [in Russian]. URL: https://www.mmbook.ru/catalog/newrologija/ neurologyo/108371-detail

13. Skoromets OA, Skoromets GP, Skoromets TO, Thyssen TP Spinal angioneurology. A guide for doctors. M: MEDpress-inform, 2003: 608 p. [in Russian]. URL: https://www.mmbook.ru/catalog/newrologija/ neurologyo/101737-detail

14. Tishevskoy IA. Anatomy of the Central Nervous System: A Textbook. - Chelyabinsk: Izd-vo YuUrGU.
2000: 131 p. [in Russian]. URL: http://pedlib.ru/ Books/4/0137/4 0137-1.shtml

15. Cherkasov VG, Kravchuk S.Yu. Human anatomy: textbook. - Vinnytsia: Nova Kniga, 2018: 640 p. [in Ukrainian]. URL: https://books.google.com.ua/books? $\mathrm{id}=\mathrm{tNmuCQAAQBAJ} \&$ printse $=$ frontcover $\& \mathrm{hl}=\mathrm{ru} \# \mathbf{v}$ $=$ onepage $\& \mathrm{q} \& \mathrm{f}=$ false

16. Aljishi M., Abernethy D. Spinal Cord Infarction // The New Zealand Medical Student Journal. 2015; 20: 18-21.

17. Bergui M., Ventilii G., Ferrio F.M., Daniele D.R. Spinal Cord Ischemia due to Vertebral Artery Dissection // Neuroradiol J. 2005 June 1; 18: 390-4. https://doi.org/1 $0.1177 \% 2 \mathrm{~F} 197140090501800318$

18. Sherman P. M., Gailloud P. Artery of the Cervical Enlargement Originating from the Inferior Thyroid Artery: An Angiographic Observation // Journal of Vascular and Interventional Radiology. 2004; 15 (6): 648-50. https://doi.org/10.1016/S1051-0443(07)603418

19. Sobotta: Anatomie des Menschen. Der komplitte Atlas in einem Band / Herausgegeben von R. Putz und R. Rabst. - Urband \& Fischer, 2007: 830 p. URL: https://1lib.eu/book/750446/a04ad5?regionChanged

20. Su W.-D., Ohtsuka A., Taguchi T., Murakami T. Typology of the Arteries in the Human Scalenus Region, with Special Reference to the Accessory Ascending Cervical Artery // Acta Med Okayama. 2000; 54 (6): 243-52. doi: 10.18926/AMO/32280.

\title{
АНАТОМІЯ КРОВОПОСТАЧАННЯ СПИННОГО МОЗКУ. ОГЛЯД
}

\author{
Черняк В.А., Шевченко О.О., Зоренко О.В., Левон М.М., Селіванов С.С., Голінко В.М.
}

\section{Національний медичний університет імені О.О. Богомольчя, Київ, Украйна masha_levon@mail.ru}

Актуальність. Традиційна схема кровопостачання спинного мозку, сформована у 60-70 роках минулого століття, не відповідає патогенезу багатьох неврологічних розладів з боку спинного мозку. Також є неузгодженість у термінології: назви артерій, що зустрічаються в роботах хірургічного та неврологічного напрямів, не відповідають назвам Міжнародної анатомічної номенклатури. Тому сьогодні це питання потребує додаткового аналізу.

Мета: узагальнити відомості різних авторів щодо кількості спинномозкових гілок та їх розгалужень, топографії, кровопостачання кожного сегменту спинного мозку, проаналізувати індивідуальну мінливість джерел кровопостачання спинного мозку.

Матеріали та методи. Аналіз наукових публікацій в міжнародній електронній наукометричній базі даних PubMed за ключовими словами за період 2000-2018pр. та співставлення цих даних з уявами 1760-1993 pp.

Результат. Змінилися уявлення про структурну організацію кровопостачання спинного мозку. Згідно сучасних даних, внутрішньочерепні джерела, а саме: передня та задні спинномозкові артерії, кровопостачають тільки верхні шийні сегменти спинного мозку, а решта сегментів - нижні шийні, грудні, поперекові, крижові та куприкові - кровопостачаються із позачерепних джерел, а саме від гілок підключичної артерії та сегментарних гілок аорти. В наш час позачерепні джерела вважаються основними в кровопостачанні спинного мозу. Сьогодні відомо, що передня та задні спинномозкові артерії $\epsilon$ перервними і не можуть забезпечити кровопостачання спинного мозку, як про це думали раніше. Загальний план артеріального кровопостачання спинного мозку можна представити у вигляді сукупності басейнів передніх і задніх корінцевих (радикуломедулярних) артерій. Передніх корінцевих артерій 4-8, а задніх 15-20, відповідно, вздовж спинного мозку в його вентральному і дорсальному відділах утворюється таке ж число артеріальних басейнів. Між цими басейнами наявні анастомотичні зв'язки, які не завжди функціонально повноцінні. Кожен $з$ цих басейнів постачається окремою радикуломедулярною артерією. Кожна така артерія живить не один, а кілька сегментів спинного мозку. Число і рівні підходу до спинного мозку радикуломедулярних артерій, особливо передніх, відрізняються значною індивідуальною мінливістю. Проаналізовано, як мінялися уявлення про васкуляризацію шийного відділу. В різні часи відомості про кількість артерій, які кровопостачали цей відділ, суттєво відрізнялися: у 1760 р. вважалося, що це 31 артерія; а у 1882-1939 рр. - всього 7; у 1943 р. - 27, у 1958 р. - 6-8; у 1958 р. - 7-10; у 1961-1963 pp. - 5-8; у 1966-1973 pp. - 5; у 1993 р. - 1-2 артерії. Такі різні відомості про васкуляризацію спинного мозку є наслідком значної індивідуальної мінливості. 
Висновки. Неповнота сучасних знань про кровопостачання спинного мозку є причиною невирішеності проблем етіології, патогенезу та клінічного перебігу спінальних ішемічних інсультів, зокрема цервікальної локалізації. Існуюча термінологічна плутанина щодо назв артерій, які кровопостачають спинний мозок, зокрема його шийний відділ, пояснюється значною варіабельністю радикуломедулярних артерій цієї зони за кількістю, діаметром та місцем відходження. У зв'язку з існуванням у цій зоні артеріо-венозних анастомозів, артеріальних міслобульбарних анастомозів, суміжних зон кровопостачання, утворюються феномени обкрадання та з'являються дистантні вогнища ішемії, що включають як спинний, так і головний мозок. Тому для постановки ангіотопічного діагнозу обов'язковим $є$ врахування не тільки анатомічних, але й фізіологічних та патофізіологічних аспектів регуляції та компенсації спинномозкового кровообігу.

Ключові слова: васкуляризація спинного мозку, шийний відділ, радикуло-медулярні артерії

\section{АНАТОМИЯ КРОВОСНАБЖЕНИЯ СПИННОГО МОЗГА. ОбЗОр}

\section{Черняк В.А., Шевченко Е.А., Зоренко Е.В., Левон М.М., Селиванов С.С., Голинко В.Н.}

\section{Национальный медицинский университет имени А.А. Богомольияа, Киев, Украина masha_levon@mail.ru}

Актуальность. Традиционная схема кровоснабжения спинного мозга, сформированная в 60-70 годах прошлого века, не соответствует патогенезу многих неврологических расстройств со стороны спинного мозга. Также есть несогласованность в терминологии: названия артерий, встречающиеся в работах хирургического и неврологического направлений, не соответствуют названиям Международной анатомической номенклатуры. Поэтому сегодня этот вопрос требует дополнительного анализа.

Цель: обобщить сведения разных авторов по количеству спинномозговых ветвей и их разветвлений, топографии, кровоснабжение каждого сегмента спинного мозга, проанализировать индивидуальную изменчивость источников кровоснабжения спинного мозга.

Материалы и методы. Анализ научных публикаций в международной электронной наукометрической базе данных РubMed по ключевым словам за период 2000-2018рр. и сопоставление этих данных с представлениями 1760-1993 гг.

Результат. Изменились представления о структурной организации кровоснабжения спинного мозга. Согласно современным данным, внутричерепные источники, а именно: передняя и задние спинномозговые артерии, питают только верхние шейные сегменты спинного мозга, а остальные сегменты - нижние шейные, грудные, поясничные, крестцовые и копчиковые кровоснабжаются внечерепными источниками, а именно от ветвей подключичной артерии и сегментарных ветвей аорты. В настоящее время внечерепные источники считаются основными в кровоснабжении спинного мозга. Сегодня известно, что передняя и задние спинномозговые артерии являются прерывистыми и не могут обеспечить кровоснабжение спинного мозга, как об этом думали раньше. Общий план артериального кровоснабжения спинного мозга можно представить в виде совокупности бассейнов передних и задних корешковых (радикуломедулярних) артерий. Передних корешковых артерий 4-8, а задних 15-20, соответственно, вдоль спинного мозга в его вентральном и дорсальном отделах образуется такое же число артериальных бассейнов. Между этими бассейнами имеются анастомотические связи, не всегда функционально полноценные. Каждый из этих бассейнов снабжается отдельной радикуломедулярною артерией. Каждая такая артерия питает не один, а несколько сегментов спинного мозга. Число и уровни подхода к спинному мозгу радикуломедулярних артерий, особенно передних, отличаются значительной индивидуальной изменчивостью. Проанализировано, как менялись представления о васкуляризации шейного отдела. В разное время сведения о количестве артерий, кровоснабжающих этот отдел, существенно отличались: в 1760 считалось, что это 31 артерия; а в 1882-1939 гг. - всего 7; в $1943-27$, в 1958 - 6-8; в 1958 - 7-10; в 1961-1963 гг. - 5-8; в 1966-1973 гг. - 5; в 1993г. - 1-2 артерии. Такие разные сведения о васкуляризации спинного мозга являются следствием значительной индивидуальной изменчивости.

Выводы. Неполнота современных знаний о кровоснабжении спинного мозга является причиной нерешенности проблем этиологии, патогенеза и клинического течения спинальных ишемических инсультов, в частности цервикальной локализации. Существующая терминологическая путаница относительно названий артерий, кровоснабжающих спинной мозг, в частности его шейный отдел, объясняется значительной вариабельностью радикуломедулярних артерий этой зоны по количеству, диаметру и месту отхождения. В связи с существованием в этой зоне артерио-венозных анастомозов, артериальных миелобульбарних анастомозов, смежных зон кровоснабжения, образуются феномены обкрадывания и появляются отдаленные очаги ишемии, включающие как спинной, так и головной мозг. Поэтому для постановки ангиотопического диагноза обязательным является учет не только анатомических, но и физиологических и патофизиологических аспектов регуляции и компенсации спинномозгового кровообращения.

Ключевые слова: васкуляризация спинного мозга, шейный отдел, радикуло-медуллярные артерии. 